\title{
The defect in the AT-like hamster cell mutants is complemented by mouse chromosome 9 but not by any of the human chromosomes
}

\author{
Wim Jongmans ${ }^{\text {a,b,1 }}$, Gerald W.C.T. Verhaegh ${ }^{\text {b,2 }}$, Nicolaas G.J. Jaspers ${ }^{c}$, \\ Peter Demant ${ }^{\mathrm{d}}$, Adayapalam T. Natarajan ${ }^{\mathrm{a}, \mathrm{b}}$, Yosef Shiloh ${ }^{\mathrm{e}}$, Mitsuo Oshimura ${ }^{\mathrm{f}}$, \\ Eric J. Stanbridge ${ }^{g}$, Raghbir S. Athwal ${ }^{h}$, Andrew P. Cuthbert ${ }^{\mathrm{i}}$, \\ Robert F. Newbold ${ }^{\mathrm{i}}$, Paul H.M. Lohman ${ }^{\mathrm{a}}$, Małgorzata Z. Zdzienicka ${ }^{\text {a,b, * }}$ \\ ${ }^{a}$ MGC-Department of Radiation Genetics and Chemical Mutagenesis, State University of Leiden, Wassenaarseweg 72, 2333 AL Leiden, \\ The Netherlands \\ ${ }^{\mathrm{b}}$ J.A. Cohen Institute, Interuniversity Research Institute for Radiopathology and Radiation Protection, Leiden, The Netherlands \\ ${ }^{c}$ MGC-Department of Cell Biology and Genetics, Erasmus University, Rotterdam, The Netherlands \\ 'Dicision of Molecular Genetics, The Netherlands Cancer Institute, Amsterdam, The Netherlands \\ 'Department of Human Genetics. Sackler School of Medicine, Tel Ativ' Unicersity, Tel Aviv, Israel \\ 'Department of Molecular and Cell Genetics, Tottori University, Yonago, Japan \\ "Department of Microbiology and Molecular Genetics, Unicersity of California, Irvine, CA, USA \\ ${ }^{\mathrm{h}}$ Department of Microbiology and Molecular Genetics, New Jersey Medical School, Newark, NJ, USA \\ 'Department of Biology and Biochemistry, Brunel University: Uxbridge, UK \\ Received 26 February 1996; revised 9 May 1996; accepted 13 May 1996
}

\begin{abstract}
X-ray-sensitive Chinese hamster V79 cells mutants, V-C4, V-L5 and V-G8, show an abnormal response to X-ray-induced DNA damage. Like ataxia telangiectasia (AT) cells, they display increased cell killing, chromosomal instability and a diminished inhibition of DNA synthesis following ionizing radiation. To localize the defective hamster gene (XRCC8) on the human genome, human chromosomes were introduced into the AT-like hamster mutants, by microcell mediated chromosome transfer. Although, none of the human chromosomes corrected the defect in these mutants, the defect was corrected by a single mouse chromosome, derived from the A9 microcell donor cell line. In four independent X-ray-resistant microcell hybrid clones of V-E5, the presence of the mouse chromosome was determined by fluorescent in situ hybridization, using a mouse cot-1 probe. By PCR analysis with primers specific for different mouse chromosomes and Southern blot analysis with the mouse $L d l r$ probe, the mouse chromosome 9, was identified in all four X-ray-resistant hybrid clones. Segregation of the mouse chromosome 9 from these hamster-mouse microcell hybrids led to the loss of the
\end{abstract}

\footnotetext{
* Corresponding author. Tel.: +31715276 175; Fax: 31 715221615.

' Current address; Unit of Mechanisms of Carcinogenesis, International Agency for Research on Cancer, Lyon, France.

${ }^{2}$ Current address: Unit of Mechanisms of Carcinogenesis, International Agency for Research on Cancer, Lyon, France.
} 
regained X-ray-resistance, confirming that mouse chromosome 9 is responsible for complementation of the defect in V-E5 cells. The assignment of the mouse homolog of the ATM gene to mouse chromosome 9, and the presence of this mouse chromosome only in the radioresistant hamster cell hybrids suggest that the hamster AT-like mutants are homologous to AT, although they are not complemented by human chromosome 11 .

Keywords: Microcell fusion; Radiosensitive hamster cell mutant; Radioresistant DNA synthesis; Ataxia-telangiectasia: Mouse chromosome 9; Mouse ATM homolog

\section{Introduction}

Ataxia telangiectasia (AT) is a rare human autosomal recessive multisystem disorder characterized by progressive neuromuscular problems, immunodeficiency, genetic instability, hypersensitivity to ionizing radiation, and proneness to cancer [1.2]. Recent cloning of the ATM ( $A T$-Mutated) gene and mutation analysis in AT patients indicate that a single AT locus on human chromosome 11q23.1 is responsible for AT [3]. Another radiosensitive, recessive, hereditary disorder, Nijmegen Breakage Syndrome (NBS) shares immunodeficiency, and cancer susceptibility with AT, but displays different clinical features, such as microcephaly and developmental delay. Although, both AT and NBS have remarkable similar cellular characteristics [4-6], recent data indicate that the gene defective in NBS is different from that of the ATM gene, and is not located on human chromosome 11 [7-9].

In search for the AT/NBS model amongst $X$ ray-sensitive rodent cell mutants, where at least eleven complementation groups have been identified (reviewed in Ref. [10]). one complementation group was recognized that closely resembles AT cells [11]. These Chinese hamster V79 cell mutants V-C4, V-E5 and V-G8 belong to complementing group 8 (XRCC8), and like AT cells, show an abnormal response to ionizing radiation-induced DNA damage, such as an increased cell killing, chromosomal instability, and a diminished inhibition of DNA synthesis. The AT-like hamster mutants display normal rates of rejoining of DNA single- and double-strand breaks, and show no increase in the frequency of induced mutations in the hypoxanthine guanine phosphoribosyl transferase (hprt) locus after X-irradiation [11,12]. The irs 2 mutant isolated by Jones et al. [13] also belongs to this complementation group, and shows characteristics similar to AT cells $[14,15]$. Despite the observed similarities of the hamster cell mutants to AT cells, it has been found that human chromosome 11 does not correct the defect in the AT-like hamster mutants [16,17], suggesting that the $X R C C 8$ gene is not homologous to the $A T$ gene.

To localize a human gene complementing the defect in the AT-like hamster mutants microcellmediated chromosome transfer was used, and all single human chromosomes were examined for complementation of X-ray-sensitivity in these hamster cell mutants. None of the human chromosomes complemented the defect in the hamster mutants, and only a single mouse chromosome 9 corrected this defect. The results suggest that the homologous human gene cannot complement the defect in these mutants. The presence of the mouse ATM homologous gene on the mouse chromosome 9 , suggests that the hamster mutants are most probably defective in the gene homologous to the human ATM gene.

\section{Materials and methods}

\subsection{Cell lines and growth conditions}

The X-ray sensitive mutants V-E5, V-C4 and V-G8 derived from Chinese hamster V79 cells have been described earlier [11,18]. A panel (listed in Table 1) of human-mouse hybrid clones of mouse A9 cells, each carrying a single, different human chromosome tagged with a dominant marker gene (agpt, gpt, hph or hprt), were used as a source of donor human chromosomes ([19-22], M.O., E.J.S., R.S.A., unpublished data).

All cultures were maintained in a $1: 1$ mixture medium of Dulbecco modified Eagle medium (DMEM) and Ham's F10 modified by the omission of hypoxanthine and thymidine, and supplemented with $10 \%$ fetal calf serum (Bodinco), penicillin (100 $\mathrm{U} / \mathrm{ml})$ and streptomycin $(0.1 \mathrm{mg} / \mathrm{ml})$. The monochromosomal A9 hybrids were maintained in 
medium supplemented with Geneticin (G418 sulphate; $800 \mu \mathrm{g} / \mathrm{ml})$, or mycophenolic acid (20 $\mu \mathrm{g} / \mathrm{ml})$ and xanthine $(70 \mu \mathrm{g} / \mathrm{ml})$, or hygromycin B $(800 \mathrm{U} / \mathrm{ml})$, or hypoxanthine $(13.6 \mu \mathrm{g} / \mathrm{ml})$, aminopterine $(0.21 \mu \mathrm{g} / \mathrm{ml})$ and thymidine $(3.1$ $\mu \mathrm{g} / \mathrm{ml}$ ), depending on the marker gene (agpt, gpt, $h p h$ or hprt, respectively) present on the human chromosome. The cultures were grown in an incubator humidified to $95-100 \%$ at $37^{\circ} \mathrm{C}$, in an atmosphere of $5 \% \mathrm{CO}_{2}$ in air.

\subsection{X-ray irradiation}

Irradiation was performed with an Andrex (SMART 325) apparatus, generating $X$-rays at a dose rate of $2.5 \mathrm{~Gy} / \mathrm{min}(200 \mathrm{kV}, 4.0 \mathrm{~mA}, 1 \mathrm{~mm} \mathrm{Al})$.

\subsection{Cell survival}

Cultures in exponential growth were trypsinized and $600-1200$ cells were seeded on $10-\mathrm{cm}$-diameter

Table 1

Microcell-mediated chromosome transferred into the AT-like hamster cell mutants

\begin{tabular}{|c|c|c|c|c|c|}
\hline Donor A9 hybrid & Human chromosome & Dominant marker gene & Recipient cells & No. hybrid clones a & $X$-ray sensitivity \\
\hline A9(neol)-4 & 1 & agpt & V-E5 & 19 & $\mathrm{~S}$ \\
\hline A9(neo2)-1 & 2 & $a g p t$ & V-E5 & 13 & $S$ \\
\hline MCH906.8 & 3 & $a g p t$ & $\mathrm{~V}-\mathrm{E} 5$ & 25 & $S$ \\
\hline A9(neo4) & 4 & agpt & V-E5 & 50 & $S^{*}$ \\
\hline A9(neo4) & 4 & $a g p t$ & $\mathrm{~V}-\mathrm{C} 4$ & 20 & s \\
\hline A9(neo4) & 4 & agpt & V-G8 & 20 & $S$ \\
\hline$A 9($ neo5)-41 & 5 & agpt & V-E5 & 19 & $\mathrm{~S}$ \\
\hline $\mathrm{MCH} 262$ & 6 & agpt & $\mathrm{V}-\mathrm{E} 5$ & 23 & $\mathrm{~S}$ \\
\hline A9(neo7)-2 & 7 & agpt & V-E5 & 30 & $S$ \\
\hline A9(neo8) & 8 & agpt & V-E5 & 9 & $S$ \\
\hline A9(neo9)-1 & 9 & $a g p t$ & V-E5 & 25 & $\mathrm{~S}$ \\
\hline $\mathrm{HA}(10)$ & 10 & $g p t$ & V-E5 & 18 & $\mathrm{~S}$ \\
\hline A9(neol1)-1 & 11 & agpt & V-E5 & 25 & $S$ \\
\hline$A 9($ neol 1$)-1$ & 11 & agpt & $\mathrm{V}-\mathrm{G} 8$ & 15 & $S$ \\
\hline $\mathrm{A} 9(2859)-3$ & $t(X / 11)^{b}$ & hprt & V-E5TG ${ }^{R}$ & 4 & $S$ \\
\hline MCH55615 & 11 & agpt & V-E5 & 10 & $S^{*}$ \\
\hline$A 9($ neol2)-5 & 12 & agpt & V-E5 & 12 & $S$ \\
\hline $\mathrm{MCH} 2043$ & 13 & agpt & V-E5 & 13 & $S$ \\
\hline RAl4Al & 14 & $g p t$ & V-E5 & 17 & $S$ \\
\hline A9(neol5)-3 & 15 & agpt & V-E5 & 12 & $S^{*}$ \\
\hline A9HYTK16 & 16 & $h p h$ & V-E5 & 6 & S \\
\hline $\mathrm{A} 9(3884)$ & $t(X / 16)^{b}$ & hprt & V-E5TG ${ }^{R}$ & 10 & $S$ \\
\hline A9(neol7)-11 & 17 & agpt & V-E5 & 14 & $S$ \\
\hline A9(neol8)-1 & 18 & agpt & V. E5 & 12 & $\mathrm{~S}$ \\
\hline A9(neo19) & 19 & agpt & V-E5 & $4^{d}$ & $S$ \\
\hline А9НYТК 19 & 19 & $h p h$ & $V-E 5$ & $4^{\mathrm{cid}}$ & $S^{*}$ \\
\hline A9(neo 20$)-3$ & 20 & agpt & $\mathrm{V}-\mathrm{E} 5$ & 13 & $S$ \\
\hline A9HYTK21 & 21 & $h p h$ & V-E5 & 12 & $\mathrm{~S}$ \\
\hline A9HYTK22 & 22 & $h p h$ & V-E5 & 13 & $\mathrm{~S}$ \\
\hline Total & & & & 467 & \\
\hline
\end{tabular}

S. sensitive.

* In these groups one X-ray resistant clone was identified.

a These numbers in some fusion represent the total of two or three independent microcell fusions.

${ }^{b}$ Carrying a recombinant chromosome, X/11: Xqter $\rightarrow X q 11:: 11 \mathrm{p} 11 \rightarrow 11$ qter, X/16: Xqter $\rightarrow X q 26:: 16 q 24-16 p t e r$.

" These hybrids did not contain a cytogenetically visible human chromosome.

"These hybrids were obtained with a very low frequency (e.g., at least 8 independent microcell fusions). 
plate, in duplicate or triplicate, and left to attach for $4 \mathrm{~h}$, then the cells were $\mathrm{X}$-irradiated in medium. After incubation for 8-10 days, the dishes were rinsed with $\mathrm{NaCl}(0.9 \%)$, air dried and stained with methylene blue $(0.25 \%)$ and visible colonies were counted. Each survival curve represents the mean of at least 3 independent experiments. The error bars represent the standard error of the mean.

\subsection{Microcell-mediated chromosome transfer}

Human chromosomes, tagged with a dominant marker gene, were transferred to recipient cells by microcell-mediated chromosome transfer as previously described by Jongmans et al. [16]. To induce micronuclei, $8 \times 10^{5}$ monochromosomal A9 hybrid cells werc seeded into $25-\mathrm{cm}^{2}$ flasks and incubated for 2 days, with an exception for A9 hybrid cells carrying the human chromosome 19 which have a reduced growth rate, and were incubated 5 days. Then, colcemid $(0.05 \mu \mathrm{g} / \mathrm{ml})$ was added, and cells were incubated for 2 more days. Only, A9 hybrid cells with human chromosome 19 were incubated for 3 more days. For enucleation, the cytochalasin-B treated cells were centrifuged in a fixed-angle GSA rotor at $8.000 \mathrm{rpm}$ for $70 \mathrm{~min}$ at $34^{\circ} \mathrm{C}$. Microcell hybrids were selected for the dominant marker gene (agpt, gpt, hph or hprt), $24 \mathrm{~h}$ after the fusion, using G418 $(400 \mu \mathrm{g} / \mathrm{ml})$, or mycophenolic acid (20 $\mu \mathrm{g} / \mathrm{ml})$ and xanthine $(70 \mu \mathrm{g} / \mathrm{ml})$, or hygromycin B $(400 \mathrm{U} / \mathrm{ml})$, or hypoxanthine $(13.6 \mu \mathrm{g} / \mathrm{ml})$, aminopterine $(0.21 \mu \mathrm{g} / \mathrm{ml})$ and thymidine $(3.1$ $\mu \mathrm{g} / \mathrm{ml}$ ), respectively. After incubation for 10 days, surviving microcell hybrid clones of V-E5 or V-G8 were isolated and expanded for evaluation of their $\mathrm{X}$-ray survival and the chromosome content.

\subsection{Fluorescence in situ hybridization}

Metaphase chromosomes were generated by $2 \mathrm{~h}$ Colcemid $(0.1 \mu \mathrm{g} / \mathrm{ml})$ treatment of cells. The cells were harvested by trypsinization and treated with 75 $\mathrm{mM} \mathrm{KCl}$ during $30 \mathrm{~min}$, and fixed in a $3: 1$ mixture of methanol and glacial acetic acid. In situ hybridization to metaphase spreads of the cell lines with biotin-labelled mouse or human cot-1 DNA was performed as described by Wiegant et al. [23] using RNase A and pepsin treated chromosomes. The bi- otin-labelled DNA was detected with FITC-conjugated avidin. The rodent chromosomes were counter stained with propidium iodide.

The presence of the human chromosomes 19, 15, $11,8,6$ and 3 , in somatic cell hybrids was determined with specific for these chromosomes biotinlabelled centromeric markers which were generously obtained from Dr. J. Wiegant.

\subsection{PCR and southern blot analysis}

Genomic DNAs, prepared from each hamster-human microcell hybrid by standard procedures [24], were amplified by PCR using simple sequences repeats (SSRs) specific for each of the mouse chromosomes as described earlier by Groot et al. [25].

For Southern blot analysis genomic DNAs (15 $\mu \mathrm{g}$ ) were digested with EcoRI, transferred to nylon membranes, and hybridized by standard procedures as described by Sambrook et al., [24]. The plasmid DNA isolated from the clone mLDLRc8 was digested with EcoRI to release a 1.5 kilobase $(\mathrm{kb})$ insert, containing the exons $8-17$ and a part of exon 18 of the mouse Ldlr gene which is located on mouse chromosome 9 [26]. The ZAP vector carrying the mousc ATM cDNA was digested with EcoRI to release a $2.0 \mathrm{~kb}$ fragment. These fragments were $\left[{ }^{32} \mathrm{P}\right] \mathrm{dCTP}$-labelled and used to hybridize with the Southern blot membranes.

\subsection{Measurement of inhibition of DNA synthesis after $\gamma$-irradiation}

The rate of DNA synthesis was measured as described by De Wit et al. [27]. Cells were prelabelled with $\left[{ }^{14} \mathrm{C}\right]$ thymidine in order to have an internal standard proportional to the amount of cells. Thereafter, cells were exposed to $\gamma$-rays emitted from a ${ }^{134} \mathrm{Cs}$-source and subsequently labelled with $\left[{ }^{3} \mathrm{H}\right]$ thymidine for $4 \mathrm{~h}$.

As an alternative to the TCA-precipitation step described by the Wit et al. [27], cells were incubated with normal medium for $1 \mathrm{~h}$, and then lysed with sodium hydroxide. The radiosensitivity was measured, and the rate of DNA synthesis was estimated from the ratio of ${ }^{3} \mathrm{H}$ to ${ }^{14} \mathrm{C}$ radioactivities, and expressed as a percentage of the ratio in unirradiated cells. Each curve represents the mean of at least 2 
independent experiments. The error bars represent the standard error of the means.

\subsection{Analysis of chromosome aberrations}

Frequencies of $\mathrm{X}$-rays-induced chromosome aberrations were determined in cells irradiated in $G_{1}$ and $G_{2}$ phase of the cell-cycle as described by Zdzienicka et al. [11]. In short, for $\mathrm{G}_{1}$ studies, confluent cultures of cells were irradiated with 1 Gy of X-rays and incubated for $16 \mathrm{~h}$. For $\mathrm{G}_{2}$ studies, exponentially growing cells were irradiated with $0.5 \mathrm{~Gy}$ and allowed to recover for $2 \mathrm{~h}$. Colcemid $(0.1 \mu \mathrm{g} / \mathrm{ml})$ was added $2 \mathrm{~h}$ before fixation. The cells were treated with hypotonic solution and fixed in acetic acid/methanol (1:3). Air-dried preparations were made and stained with Giemsa. Fifty cells per point were examined for the presence of chromosome aberrations.

\subsection{Segregation of chromosomes in the microcell hybrids}

To isolate segregants which lost the transferred human chromosome (tagged with the dominant marker gene agpt) or the $\mathrm{X}$-ray complementing mouse chromosome, cells were grown for more than one month in nonselective medium without G418. The agpt or X-ray-sensitive segregants were isolated by replica plating as described earlier by Zdzienicka and Simons [18] using medium containing G418 or camptothecin, respectively. To detect X-ray sensitive segregant clones that lost the complementing mouse chromosome 9, the replica plates containing medium with camptothecin were used, since previously, it has been shown that the AT-like hamster mutants are also very sensitive to this agent [17].

\section{Results}

\subsection{Complementation of X-ray sensitivity of $V-E 5$ cells by microcell-mediated chromosome transfer}

In order to determine which human chromosome complements the X-ray sensitivity of the AT-like hamster cell mutants (V-E5, V-C4 and V-G8), microcell-mediated chromosome transfer to introduce different human chromosomes into these cells, was used. For each human chromosome several microcell hybrid cloncs werc isolated after selection for the dominant marker gene (Table 1). The presence of each human chromosome in the obtained microcell hybrids was examined by fluorescent in situ hybridization, using human cot-1 DNA as a probe. Although, most hybrids contained cytogenetically normal human chromosomes, none of these chromosomes was able to correct the X-ray sensitivity of the hamster mutants. However, from each cross between V-ES cells and microcells containing the human chromosome $4,11,15$ and 19 , one $\mathrm{X}$-ray resistant microcell hybrid clone was isolated. The hybrid clones V-E5neo4-21, V-E5neo 11-39 and VE5neo 156 showed an intermediate X-ray survival, whereas
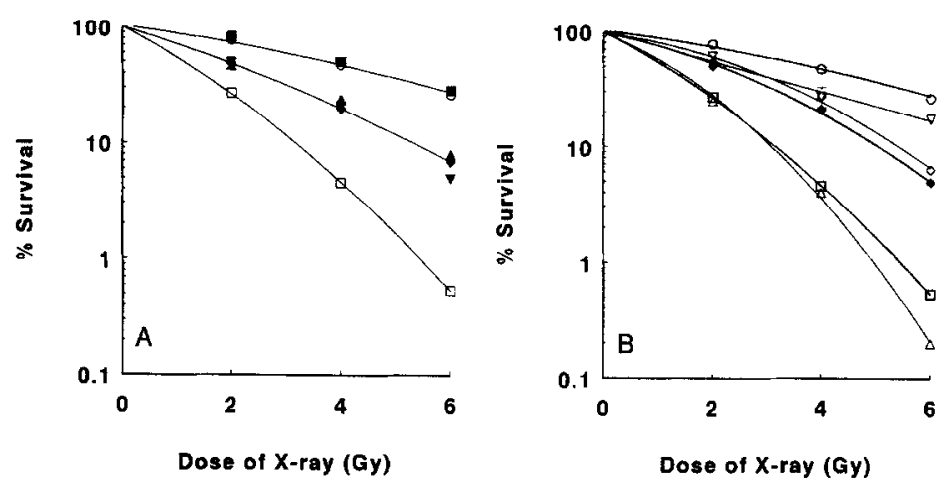

Fig. 1. X-ray survival curves of (A) V79 (O), V-E5 ( $\square$ ), and the microcell hybrid clones V-E5neo4-21 ( $\bullet)$, V-E5neol1-39 (A),

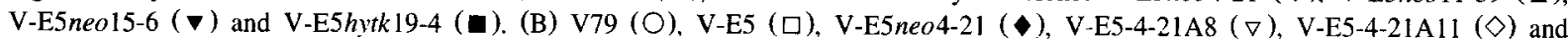
V-E5-4-21S $(\Delta)$ 
the hybrid clone V-E5hytk19-4 displayed survival similar to wild-type V79 cells (Fig. 1A).

The observed frequency of the $\mathrm{X}$-ray resistant hybrid clones amongst all microcell hybrids was very low $(0.8 \%)$, and it seems unlikely that different human chromosomes may correct the X-ray sensitivity of V-E5 cells. Therefore, these results suggested that a co-introduced mouse chromosome could be responsible for the observed correction. Indeed, by fluorescent in situ hybridization using mouse cot-1 DNA as a probe, it was found that in all four $\mathrm{X}$-ray-resistant microcell hybrid clones of V-E5, a single mouse chromosome, derived from the mouse A9 donor cell line, was co-introduced with the human chromosome [28].

\subsection{Identification of the complementing mouse chro- mosome 9}

The mouse chromosome 9 was identified in the X-ray resistant hybrid clones: V-E5nen4-21 and VE5neo15-6, by PCR using mouse chromosome specific SSRs (Fig. 2). The presence of mouse chromosome 9 was confirmed in all the X-ray-resistant hybrid clones V-E5neo4-21, V-E5neo11-39, VE5neo15-6, and V-E5hytk19-4 by Southern blot analysis, using the mouse Ldlr probe (Fig. 3A and B). The used mouse Ldlr probe hybridizes with the

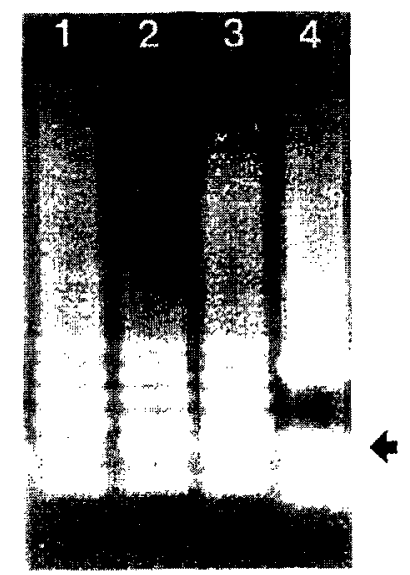

Fig. 2. Analysis of PCR products with the mouse primer set D9Mit42. DNA from V-E5 (lane 1), A9 mouse (lane 4), and the hybrid clones V-E5neo4-21 (lane 2), and V-E5neo15-6 (lane 3) was amplified with the D9Mit42 primerset and the products were separated by electrophoresis in $0.8 \%$ agarose.

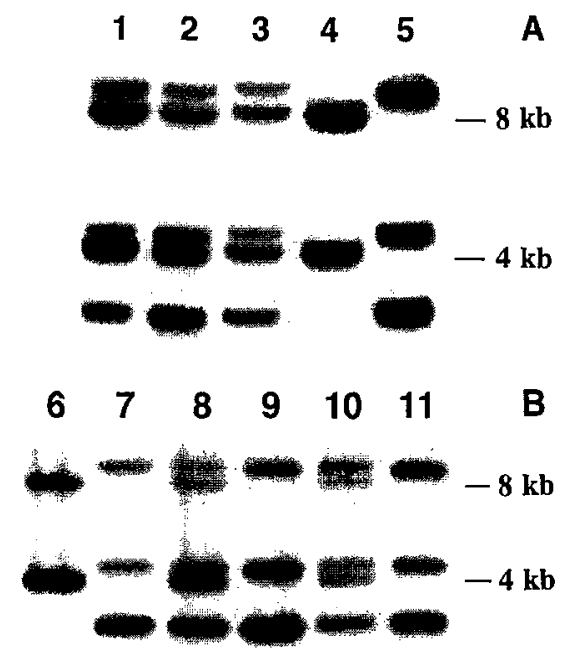

Fig. 3. Southern blot hybridization of a $1.500 \mathrm{kh}$ DNA fragment of the mouse Ldlr cDNA with EcoRI digested DNA from (A) V-E5neo4-2l (lane 1), V-E5hytk19-4 (lane 2), V-E5neo11-39 (lane 3). A9 mouse (lane 4), V-E5 (lane 5) and (B) A9 mouse (lane 6), V-E5 (lane 7), V-E5neo4-21 (lane 8), V-E5-4-21S (lane 9), V-E5neol5-6 (10). V-E5neo11-6 (11).

two EcoRI fragments of the mouse $L d l r$ gene, 8 and $4 \mathrm{~kb}$ in size. Although, this mouse Ldlr probe crosshybridizes with the hamster Ldlr gene, the three $E c o$ RI fragments it hybridizes with, are clearly distinct in size $(8.5,4.3$ and $3 \mathrm{~kb})$.

To establish whether the mouse chromosome 9 is responsible for the observed correction of X-ray sensitivity in V-E5neo4-21 containing also a human chromosome 4, several segregants, which had lost either the human or mouse chromosome, were isolated by replica plating. Several G418-sensitive clones, V-E.5-4-21A8 and V-E5-4-21A11 displayed the $\mathrm{X}$-ray resistance similar to the parental cell line V-E5neo4-21 (Fig. 1B). All these clones contained the complementing mouse chromosome 9 , but had lost the human chromosome 4 , as was determined by fluorescent in situ hybridization using either human or mouse cot-1 DNA as a probe (data not shown). Only one G-418-resistant but X-ray sensitive clone V-E5-4-21S was isolated (Fig. 1B). The X-ray sensitivity of these cells was similar to V-E5 or hybrids of V-E5 cells with a single human chromosome 11 (V-E5neo11-6). By Southern blotting, using the mouse LdIr probe this clone was shown to have lost the mousc chromosome 9 (Fig. 3B), although V-E5- 
4-21S contained a minute part of the mouse chromosome integrated into a hamster chromosome, as determined by fluorescent in situ hybridization, using mouse cot-1 DNA as a probe (data not shown). These results indicate that mouse chromosome 9, and not human chromosome 4 , is responsible for the observed complementation of the X-ray sensitivity in the AT-like hamster mutants.

\subsection{Inhibition of DNA synthesis after $\gamma$-irradiation in V-E5 cells containing mouse chromosome 9}

To determine whether mouse chromosome $9 \mathrm{com}$ plements the radioresistant DNA synthesis (RDS) of V-E5 hamster mutant cells, the rate of DNA synthesis after $\gamma$-irradiation in the X-ray-resistant hybrid clones (V-E5neol1-39, V-E5neo15-6 and VE5hytk 19-4) was examined. Normal inhibition of DN $\Lambda$ synthesis after $\gamma$-irradiation (i.e., similar to wild-type V79 cells) was only observed in one hybrid clone (V-E5hytk19-4), whereas in the other hybrid clones (V-E5neol 1-39 and V-E5neol5-6) radioresistant DNA synthesis, similar to the parental V-E5 cell line (Fig. 4) was found. The inhibition of DNA synthesis after $\gamma$-irradiation in the $X$-ray-resistant hybrid clone V-E5neo4-21 containing human chromosome 4 was much more pronounced than in wild-type hamster cells. Further studies with hurnan chromosome 4 have shown that a gene on human

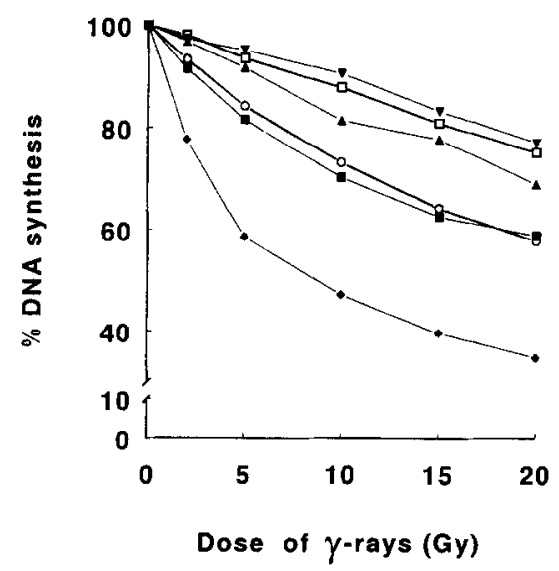

Fig. 4. Dose-response curve of the rate of DNA synthesis after $\gamma$-irradiation of V79 (O), V-E5 ( $\square)$, and the microcell hybrid

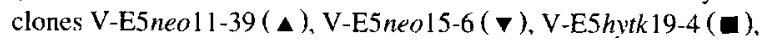
and V-E5neu4-21 (*).
Table 2

Spontaneous and X-ray-induced chromosomal aberrations in the AT-like V-E5 cells and in hybrids between V-E5 and mouse chromosome 9, in $\mathrm{G}_{1}$ and $\mathrm{G}_{2}$

\begin{tabular}{|c|c|c|c|c|c|c|c|c|c|}
\hline \multirow[t]{2}{*}{ Cell line } & \multirow{2}{*}{$\begin{array}{l}\text { Dose } \\
(G y)\end{array}$} & \multicolumn{8}{|c|}{ Aberrations $/ 50$ cells } \\
\hline & & $\widehat{A b n}{ }^{*}$ & $\mathrm{G}^{\prime}$ & $\mathrm{G}^{\prime \prime}$ & $\mathrm{B}^{\prime}$ & $\mathrm{B}^{\prime \prime}$ & Ex & $\begin{array}{l}\text { Dic } \\
+ \text { ring }\end{array}$ & Total \\
\hline \multicolumn{10}{|l|}{ Controls } \\
\hline V79 & 0 & 6 & & 0 & & 0 & 0 & 0 & 6 \\
\hline V-E5 & 0 & 14 & 4 & 0 & 13 & 0 & 0 & 3 & 20 \\
\hline V-E5neo11-39 & 0 & 10 & 7 & 0 & 6 & 0 & 0 & 0 & 13 \\
\hline V-E5neo15-6 & 0 & 14 & 5 & 1 & 5 & 0 & 1 & 4 & 16 \\
\hline V-EShytk 19-4 & 0 & 5 & 3 & 0 & 1 & 0 & 1 & 1 & 6 \\
\hline \multicolumn{10}{|l|}{$\mathrm{G}_{1}$ cells } \\
\hline V79 & 1 & 10 & & 1 & 2 & 0 & 0 & 5 & 10 \\
\hline V-E5 & 1 & 34 & 9 & 1 & 32 & 0 & 7 & 12 & 61 \\
\hline V-E5neo11-39 & 1 & 37 & 16 & 3 & 40 & 0 & 10 & 5 & 74 \\
\hline V-E5neo15-6 & 1 & 39 & 7 & 0 & 30 & 4 & 17 & 3 & 61 \\
\hline V-E5hytk19-4 & 1 & 29 & 21 & 0 & 7 & 0 & 8 & 7 & 43 \\
\hline \multicolumn{10}{|l|}{$\mathrm{G}_{2}$ cells } \\
\hline V79 & 0.5 & 20 & 14 & 0 & 8 & 0 & 0 & 0 & 22 \\
\hline V-F.5 & 0.5 & 40 & 18 & 0 & 66 & 0 & 3 & 3 & 90 \\
\hline V-E5neo11-39 & 0.5 & 32 & 12 & 0 & 61 & 0 & 1 & 0 & 74 \\
\hline V-E5neo 15-6 & 0.5 & 46 & 23 & 0 & 80 & 0 & 5 & 1 & 109 \\
\hline V-EShyzk19-4 & 0.5 & 37 & 17 & 2 & 46 & 0 & 0 & 1 & 66 \\
\hline
\end{tabular}

* Abn., abnormal cells amongst 50 normal cells: $G^{\prime}$, chromatid gap: $G^{\prime \prime}$, isochromatid gap; $\mathbf{B}^{\prime}$, chromatid break: $\mathrm{B}^{\prime \prime}$, isochromatid/chromosome break; Ex, chromatid exchange; Dic + ring, dicentric chromosome and centric ring.

chromosome $4 \mathrm{q}$, is responsible for the regulation of DNA synthesis after ionizing radiation [17].

\subsection{Effect of mouse chromosome 9 on spontaneous and $X$-ray-induced chromosome aberrations in V-E5 cells}

To determine whether mouse chromosome 9 complements chromosomal instability observed in the AT-like hamster mutants, the spontaneous and Xray-induced chromosome aberrations in the hybrid clones V-E5neo11-39, V-E5neo15-6, and VE5hytk 19-4, were examined. The frequency of spontaneous chromosomal aberrations was slightly lower in V-E5neo11-39, V-E5neo 15-6 hybrids, whereas in V-E5hytk 19-4 it was similar to that observed in wild-type V79 cells. The presence of mouse chromosome 9 showed no effect on the frequency of the $\mathrm{X}$-ray-induced chromosomal aberrations, in all hy- 
brid clones (Table 2). This indicates that mouse chromosome 9 only partially complements the defect in the AT-like hamster mutants.

\subsection{Chromosomal localization of the ataxia telang- iectasia mouse homolog}

The chromosomal region 11q22-23 where the ATM gene has been localized, shows syntenic homology with mouse chromosome 9 [29]. Therefore, by Southern blot analysis we determined whether the mouse homolog of the ATM gene localizes to mouse
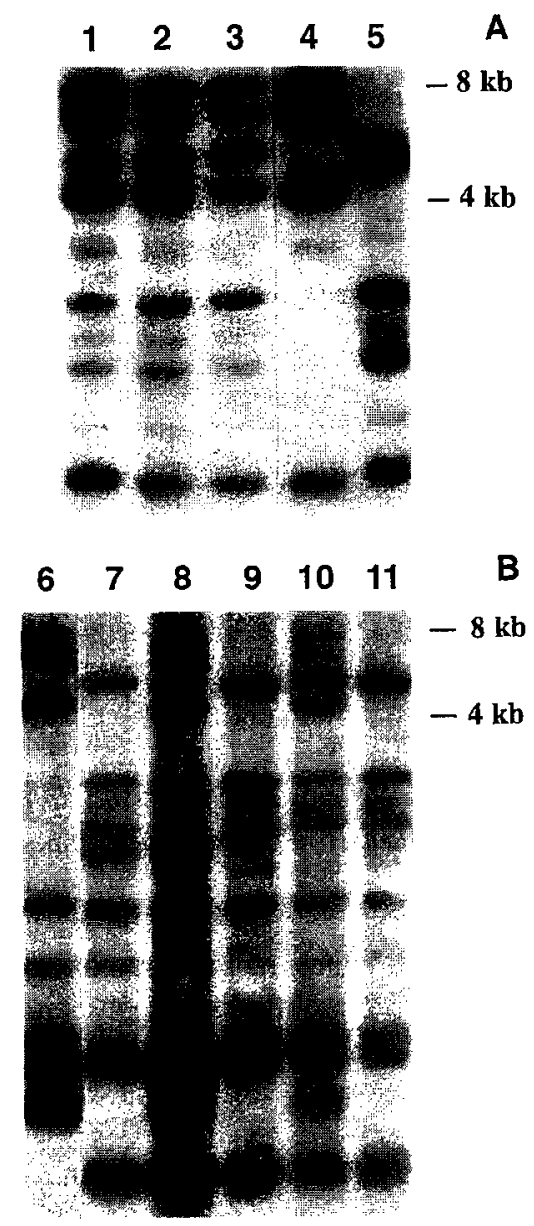

Fig. 5. Southern blot hybridization of a $2 \mathrm{~kb}$ DNA fragment of the mouse ATM CDNA with EcoRI digested DNA from (A) VE5neo4-21 (lane 1), V-E5hytk19-4 (lane 2), V-E5neo11-39 (lane 3), A9 mouse (lane 4), V-E5 (lane 5) and (B) A9 mouse (lane 6), V-E5 (lane 7), V-E5neo4-21 (lane 8), V-E54-21S (lane 9), VE5neo15-6 (10), V-E5neol1-6 (11). chromosome 9, which is present in the X-ray-resistant hybrid clones: V-E5neo4-21, V-E5neo11-39, V-E5neo15-6, and V-E5hytk 19-4 (Fig. 5). Hybridization of the mouse ATM probe to EcoRI-digested genomic mouse DNA gives a nine fragment ladder from $7.5,7,4.5$ to $0.5 \mathrm{~kb}$. Although, this mouse ATM probe cross-hybridizes with genomic hamster DNA, a clearly different eight fragment ladder from 6,3 to $0.1 \mathrm{~kb}$ is seen in hamster cells. Both, the mouse and hamster, ATM ladders were present in the hybrid clones carrying mouse chromosome 9, whereas only the hamster ATM ladder was present in the X-ray sensitive clone V-E54-21S which contained only a small part of mouse chromosome 9 . This indicates that the mouse ATM homolog is located on the mouse chromosome 9 . No change in the ATM fragment ladder (e.g., no cross-hybridization) was seen in the hybrid clone V-E5neo11-39 carrying in addition to mouse chromosome 9, also human chromosome 11 , or in the hybrid clone $\mathrm{V}$ E5neol1-6 carrying only human chromosome 11.

\section{Discussion}

The X-ray sensitive hamster cell mutants of group 8 display cellular characteristics of $\Lambda \mathrm{T}$ cells $[11,12]$, but the defect in these AT-like mutants is not complemented by human chromosome 11 [16,17], where the $A T$ gene is located. Surprisingly, all human autosomes failed to correct the increased X-ray sensitivity of the AT-like hamster cells when introduced by microcell-mediated chromosome transfer (Table 1). Several hybrid clones between AT-like cells (hprt ${ }^{-}$) and human lymphocytes containing chromosome $X$ with few other human chromosomes, remained X-ray-sensitive (data not shown). Since these hybrids were selected for the human hprt gene, which is located on the $\mathrm{X}$ chromosome, this indicates that the chromosome $\mathrm{X}$ is not carrying the correcting gene. While the human chromosomes failed to correct the defect in the AT-like mutants, mouse chromosome 9 which shows syntenic homology with human chromosome 11q22-23 [29] complemented the defect in these mutants. The mouse chromosome 9 shows homology also with human chromosomes 3 . $6,8,15$, and 19 [29] but all these chromosomes 
failed to complement the defect in the AT-like mutants, both in the microcell hybrids, as well as in several X-ray sensitive hybrid clones between these hamster mutants and normal human lymphocytes which contained these chromosomes (data not shown).

The results presented in this paper indicate that the mouse homolog of the ATM gene is localized on mouse chromosome 9 , and this mouse chromosome complements the defect in the AT-like hamster cell mutants. This suggests that the $A T M$ gene and the hamster XRCC 8 gene could be homologs, despite that human chromosome 11 does not correct the defect in these mutants. Numerous explanations could account for the observed lack of complementation by human chromosomes. First, this could result from the loss of parts of the human chromosomes during the microcell-mediated chromosome transfer procedure. Although, when such loss occurs, its frequency is found to be less than $40 \%$ [30-37]. Since we have examined multiple independent microcell hybrid clones of the AT-like mutants for each of the human chromosomes, the consistent lack of correction due to the loss of a complementing gene during microcell chromosome transfer, is rather unlikely. Second, the lack of correction could be due to epigenetic alterations of the human chromosomes in the hamster cell background. However, there are no data to support this assumption, since the defect in most of the X-ray sensitive rodent cell mutants could be complemented by the transfer of a single human chromosome (reviewed in Ref. [10]; and references therein). Finally, the lack of correction by a human chromosome could be due to inadequacy in functional homology between the human and hamster gene, resulting in an inability of the human gene product to correct the mutant phenotype of the AT-like hamster cells.

Analysis of the functional complementation of the AT-like mutants by mouse chromosome 9 , revealed that RDS was only occasionally corrected in the hybrids between the AT-like hamster mutants and mouse chromosome 9. A similar, sporadic complementation of cell killing without correction of RDS has been observed with DNA-mediated gene transfer into AT cells [36,38-40], or after cell fusion of AT cells with normal human cells [41], or in AT cells containing an extra copy of human chromosome 11 [36.41]. Comparable results have been observed with
DNA-mediated gene transfer into the AT-like V-E5 hamster cells [28].

Numerous results have indicated that DNA replication after ionizing radiation is controled by several factors, but sofar the mechanisms involved are not well understood. In cell hybrids between the AT-like hamster mutants and wild-type V79 cells co-dominance of RDS has been demonstrated [42], indicating that this marker cannot be used for genetic complementation of rodent X-ray-sensitive mutants. However, RDS has been used as marker for complementation studies with AT cells, and 4 complementation groups have been identified [43]. The identification of one ATM gene [3] has indicated that RDS is not a reliable marker for complementation of human cells, either. Recently, we have found that the introduction of human chromosome $4 \mathrm{q}$ into V-E5 cells, strongly amplifies the level of inhibition of DNA synthesis after $\gamma$-irradiation, without correcting the X-ray-induced chromosomal aberrations or cell killing [17] indicating that complex mechanisms are responsible for RDS. Therefore, it is very difficult to explain why mouse chromosome 9 fully complemented the defect in RDS in the AT-like mutants only in one hybrid clone, whereas a partial or lack of complementation was observed in the remaining hybrids.

The hypothesis that cell killing by $\mathrm{X}$-irradiation is primarily due to X-ray-induced chromosome aberrations is well documented [44-47]. Also, the introduction of human chromosome 11 into AT cells corrected cell killing by $\mathrm{X}$-rays as well as X-ray-induced chromosome aberrations [48]. However, in the AT-like V-E5 hamster cells with mouse chromosome 9, it appears that correction of cell killing by X-rays is not due to the correction of X-ray-induced chromosome aberrations. This suggests that cell killing, $\mathrm{X}$-ray induced chromosome aberrations, as well as RDS, are all independently modulated by the $X R C C 8$ gene product which is defective in V-E5 cells. The lack of complementation of the $\mathrm{X}$-ray-induced chromosome aberrations in V-E5 cells by mouse chromosome 9 , could be explained by a possible insufficient functional homology between the hamster and mouse gene product.

Identification of the gene mutated in $\mathrm{AT}$ patients revealed that this heterogeneous disease is caused by mutations in a single gene ATM [3]. The carboxyl terminus of this $A T M$ gene product shows similari- 
ties to the catalytic domains of phosphatidylinositol 3-kinase (PI 3-kinase). This similarity is shared with a family of ATM-related genes and includes the $M E C I$ and $T E L 1$ genes in budding yeast, the RAD3 gene in fission yeast, the Drosophila melanogaster $M E I-41$ gene, the mammalian DNA-dependent protein kinase $D N A-P K_{c s}$, and the mammalian and yeast $T O R$ genes (reviewed in Ref. [49]). These gene products are involved in the processing of DNA damage, maintenance of genome stability and the control of cell cycle progression, all processes found to be defective in AT. As PI 3-kinase is involved in signal transduction, the ATM gene product is implicated in a signal transduction pathway that activate multiple cellular functions in response to DNA damage. It seems probable that other genes downstream this pathway, when defective, may lead to the same cellular phenotypes as observed in AT cells. Therefore, in addition to AT and NBS other mutants with the AT phenotype might be identified.

The existence of a family of $A T M$-related genes implies that a very strict homology is required to perform the specific function of each gene. Therefore, the observed lack of complementation of the defect in the AT-like mutants by human chromosomes could be due to the inadequacy of functional homology between the rodent and human XRCC 8 gene product. Although, our results suggest that the ATM gene is the 'true' homolog of the gene defective in the AT-like hamster mutant, this still remains to be proven by the identification of mutations in the hamster AT gene.

\section{Acknowledgements}

We thank Drs. Bruno Morroli, Ings. Wilfred M.F. Tuurenhout, and Matty Meijers for their skilful technical assistance.

\section{References}

[1] Sedgwick, R.P. and E. Boder (1991) Ataxia-telangiectasia, in: J.M.B.V. de Jong (Ed.), Heriditary Neuropathies and Spinocerebellar Atrophies. Handbook of Clinical Neurology, Vol. 16, Elsevier Science B.V., Amsterdam, pp. 347-423.

[2] Shiloh, Y. (1995) Ataxia-telangiectasia: Closer to unraveling the mystery, Eur. J. Hum. Genet., 3, 116-138.
[3] Savitsky, K., A. Bar-Shira, S. Gilard, G. Rotman, Y. Ziv, L. Vanagaite, D.A. Tagle, et al. (1995) A single ataxiatelangiectasia gene with a product similar to PI-3-kinase, Science, 268, 1749-1753.

[4] Weemaes C.M., T.W. Hustinx, J.M. Scheres, P.J. van Munster, J.A. Bakkeren and R.D. Taalman (1981) A new chromosomal instability disorder: the Nijmegen breakage syndrome, Acta Paediatr. Scand., 70, 557-564.

[5] Weemaes C.M.. D.F.C.M. Smeets and C.J.A.M. van der Burgt (1994) Nijmegen breakage syndrome: a progress report, Int. J. Radiat. Biol., 66, S185-S188.

[6] Curry, C.J.R., J. Tsai, N.T. Hutchinson, N.G.J. Jaspers, D. Wara and R.A. Gatti (1989) A-T-Fresno: a phenotype linking ataxia-telangiectasia with the Nijmegen breakage syndrome, Am. J. Hum. Genet., 45, 270-275.

[7] Gatti, R.A., E. Lange, G. Rotman, X. Chen, N. Uhrhammer, T. Liang, S. Chiplunkar et al. (1995) Genetic haplotyping of ataxia-telangiectasia families localizes the major gene to an $850 \mathrm{~kb}$ region on chromosome 1 l q23.1, Int. J. Radiat. biol., 66, S57-S62.

[8] Komatsu, K.. H. Tauchi, S. Endo, S. Kodama, M. Oshimura, D. Smeets and C. Weemaes (1995) Lack of complementation of radiation sensitivity in Nijmegen Breakage Syndrome cell line by the normal chromosome 11, in: U. Hagen, H. Jung and C. Streffer (Eds.), Proceedings of 10th International Congress of Radiation Research Würzburg, Germany, Vol. 1. Congress Abstracts, pp. 300.

[9] Stumm. M.. R.A. Gatti, A. Reis, N. Udar, K. Chrzanowska, E. Seemanova, K. Sperling and R.D. Wegner (1995) The ataxia-telangiectasia-variant genes $\mathrm{I}$ and 2 are distinct from the ataxia-telangiectasia gene on chromosome 11q23.1. Am. J. Hum. Genet., 57, 960-962.

[10] Zdzienicka, M.Z. (1995) Mammalian mutants defective in the response to ionizing radiation-induced DNA damage, Mutation Res., 336. 203-213.

[11] Zdzienicka, M.Z., N.G.J. Jaspers, G.P. van der Schans, A.T. Natarajan and J.W.I.M. Simons (1989) Ataxiatelangiectasia-like Chinese hamster V79 cell mutants with radioresistant DNA synthesis, chromosomal instability, and normal DNA strand break repair, Cancer Res., 49, $1481-$ 1485.

[12] Jongmans, W.. G.W.C.T. Verhaegh, K. Sankaranarayanan, P.H.M. Lohman and M.Z. Zdzienicka (1993) Cellular characteristics of Chinese hamster cell mutants resembling ataxiatelangiectasia cells, Mutation Res., 294, 207-214.

[13] Jones. N.J., R. Cox and J. Thacker (1987) Isolation and cross-sensitivity of X-ray-sensitive mutants of V79-4 hamster cells, Mutation Res., 183, 279-286.

[14] Thacker, J. and A.N. Ganesh (1990) DNA-break repair, radioresistance of DNA synthesis, and camptothecin sensitivity in the radiation-sensitive irs mutants: com parisons to ataxia-telangiectasia cells, Mutation Res.. 235, 49-58.

[15] Jones, N.J., S.A. Stewart and L.H. Thompson (1990) Biochemical and genetic analysis of the Chinese hamster mutants irs 1 and irs2 and their comparison to cultured ataxiatelangiectasia cells. Mutagenesis, 5, 15-23.

[16] Jongmans, W., J. Wiegant, M. Oshimura, M.R. James, P.H.M. 
Lohman and M.Z. Zdzienicka (1993) Human chromosome 11 complements ataxia telangiectasia cells but does not complement the defect in AT-like chinese hamster cell mutants. Human Genet., 92, 259-264.

[17] Verhaegh, G.W.C.T., W. Jongmans, N.G.J. Jaspers, A.T. Natarajan, M. Oshimura, P.H.M. Lohman and M.Z. Zdzienicka (1995) A gene that regutates DNA replication in response to DNA damage is located on human chromosome 4q. Am. J. Hum. Genet.. 57. 1095-1103.

[18] Zdzienicka, M.Z. and J.W.I.M. Simons (1987) Mutagen-sensitive cell lines are obtained with a high frequency in V79 Chinese hamster cells, Mutation Res., 178, 235-244.

[19] Koi, M., M. Shimizu, H. Morita, H. Yamada and M. Oshimura (1989) Construction of mouse A9 clones containing a single human chromosome tagged with neomycin-resistance gene via microcell fusion, Jpn. J. Cancer Res., 80, 41.3-418.

[20] Koi, M., H. Morita, M. Shimizu and M. Oshimura (1989) Construction of mouse $\mathrm{A} 9$ clones containing a single human chromosome ( $\mathrm{X} /$ autosome translocation) via micro cell fusion, Jpin. J. Cancer Res., 80, 122-125.

[21] Lambet, C.. R.A. Schultz, M. Smith, C. Wagner-McPerson. L.D. McDaniel, T. Donlon. E.J. Stanbridge. et al. (1991) Functional complementation of ataxia-telangiectasia group D (AT-D) cells by microcell-mediated chromosome transfer and mapping of the AT-D locus to the region 11,?2-23, Proc. Natl. Acad. Sci. USA. 88, 5907-5911.

[22] Cuthbert, A.P., D.A. Trott, R.M. Ekong, S. Jezzard, N.L. England, M. Themis, C.M. Todd and R.F. Newbold (1995) Construction and characterization of a highly stable human:rodent monochromosomal hybrid panel for genetic complementation and genome mapping studies. Cytogenet. Cell Genet.. 71, 68-76.

[23] Wiegant, J., T. Ried, P.M. Nederlof, M. van der Ploeg, H.J. Tanke and A.K. Raap (1991) In situ hybridization with fluoresceinated DNA, Nucleic Acid Res., 19. 3237-3241.

[24] Sambrook, J.. E.F. Fritsch and T. Maniatis (1989) Molecular cloning: a laboratory manual. Cold Spring Harbor Laboratory. Cold Spring Harbor. NY.

[25] Groot, P.C., C.J.A. Moen, W. Dietrich, J.P. Stoye, E.S. Lander and P. Demant (1992) The recombinant congenic strains for analysis of multigenic traits: genetic composition. FASEB J.. 6, 2826-2835.

[26] Hoffer, M.J.V., M.M. van Eck, P. Petrij, A. van der Zee, E. de Wit. D. Meijer. G. Grosveld, L.M. Havekes. M.H. Hotker and R.R. Frants (1993) The mouse low density lipoprotein receptor gene: cDNA sequence and exon-intron structure, Biochem. Biophys. Res. Commun., 191, 880-886.

[27] Wit de. J., N.G.J. Jaspers and D. Bootsma (1981) The rates of DNA synthesis in normal human and ataxia-telangiectasia cells after exposure to X-irradiation. Mutation Res., 80 , $221-226$.

[28] Zdzienicka. M.Z., G.W.C.T. Verhaegh, W. Jongmans, B. Morolli, N.G.J. Jaspers, and M. Oshimura (1995) Functional complementation studies with $\mathrm{X}$-ray-sensitive mutants of Chinese hamster cells closely resembling ataxia-telangiectasia cells, Int. J. Radiat. Biol., 6. 189-195.

[29] Copeland. N.G.. N.A. Jenkins. D.J. Gilbert. J.T. Fppig. I.J.
Maltais, J.C. Miller, Dietrich WF et al. (1993) A genetic linkage map of the mouse: current applications and future prospects, Science, 262, 57-66.

[30] Saxon, P.J., R.A. Schultz, E.J. Stanbridge and E.C. Fricdberg (1989) Human chromosome 15 confers partial complementation of phenotypes to xeroderma pigmentosum group $F$ cells, Am. J. Hum. Genet., 44, 474-485.

[31] Ishizaki, K., M. Oshimura, M.S. Sasaki, Y. Nakamura and M. Ikenaga (1990) Human chromosome 9 can complement UV sensitivity of xeroderma pigmentosum group A cells, Mutation Res., 235, 209-215.

[32] Ejinna, Y., M. Oshimura and M.S. Sasaki (1991) Determination of the chromosomal site for the human radiosensitive ataxia-telangiectasia gene by chromosome transfer. Mutation Res., 250, 337-343.

[33] Flejter, W.L.. L.D. McDaniel, D. Johns, E.C. Friedberg and R.A. Schultz (1992) Correction of xeroderma pigmentosum complementation group $\mathrm{D}$ mutant cells phenotypes by chromosome and gene transfer: Involvement of the human ERCC2 DNA repair gene, Proc. Natl. Acad. Sci. USA, 89, 261-265.

[34] Chen. D.J., M.S. Park, E. Campbell, M. Oshimura, P. Liu, Y. Zhao. B.F. White and M.J. Siciliano (1992) Assignment of a human DNA double-strand break repair gene (XRCC5) to chromosome 2. Genomics, 13. 1088-1094.

[35] Jeggo P.A. M. Hafezparast, A.F. Thompson, B.C. Broughton, G.P. Kaur, M.Z. Zdzienicka and R.S. Athwal (1992) Localization of a DNA repair gene (XRCC5) involved in double-strand-break rejoining to human chromosome 2. Proc. Natl. Acad. Sci. USA, 89. 6423-6427.

[36] Jongmans, W.. G.W.C.T. Verhaegh. N.G.J. Jaspers, M. Oshimura, E.J. Stanbridge, P.H.M. Lohman and M.Z. Zdzienicka (1995) Studies on phenotypic complementation of ataxia-telangiectasia cells by chromosome transfer. Am. J. Hum. Genet.. 56, 438-443.

[37] Zdzienicka. M.Z.. W. Jongmans. M. Oshimura, A. Priestley, G.F. Whitmore and P.A. Jeggo (1995) Complementation analysis of the murine scid cell line, Radiat. Res., 143, $238-274$.

[38] Lehmann, A.R.. C.F. Arlett. J.F. Burke, M.H. Green, M.R. James and J.E. Lowe (1986) A derivative of an ataxiatelangiectasia (A-T) cell line with normal radiosensitivity but A-T-like inhibition of DNA synthesis, Int. J. Radiat. Biol,, 49. 639-643.

[39] Green. M.H., J.E. Lowe, C.F. Arlett, S.A. Harcourt, J.F Burke. M.R. James, A.R. Lehmann et al. (1987) A gammaray-resistant derivative of an ataxia-telangiectasia cell line obtained following DNA-mediated gene transfer, J. Cell Sci. Suppl., 6, 127-137.

[40] Kapp, L.N. and R,B. Painter (1989) Stable radioresistance in ataxia-telangiectasia cells containing DNA from normal human cells, Int. Radiat. Biol., 56, 667-675.

[41] Komatsu, K.. Y. Okumura, S. Kodama, M. Yoshida and R.C. Miller (1989) Lack of correlation between radiosensitivity and inhibition of DNA synthesis in hybrids (A-T $\times$ HeLa), Int. J. Radiat. Biol., 56, 863-867.

[42] Verhaegh. G.W.C.T., N.G.J. Jaspers, P.H.M. Lohman and M.7. 7.d7ienicka (1993) Co-dominance of radioresistant DNA 
synthesis in a group of AT-like Chinese hamster cell mutants, Cytogenet. Cell Genet., 63, 176-180.

[43] Jaspers, N.G.J., R.A. Gatti, C. Baan, P.C. Linssen and D. Bootsma (1988) Genetic complementation analysis of ataxia-telangiectasia and Nijmegen breakage syndrome: a survey of 50 patients, Cytogenet. Cell Genet., 49, 259-263.

[44] Carrano, A.V. (1973) Chromosome aberrations and radiation-induced cell death, I. Transmission and survival parameters of aberrations, Mutation Res.. 17, 341-353.

[45] Carrano, A.V. (1973) Chromosome aberrations and radiation-induced cell death, $\mathrm{II}$. Predicted and observed cell survival, Mutation Res., 17, 355-366.

[46] Bedford. J.S., J.B. Michell, H.G. Griggs and M.A. Bender
(1978) Radiation-induced cellular reproductive death and chromosome aberrations, Radiat. Res., 76, 573-586.

[47] Cornforth, M.N.. and J.S. Bedford (1987) A quantitative comparison of potentially lethal damage repair and the rejoining of interphase chromosome breaks in low passage normal human fibroblasts, Radiat. Res., 111. 385-405.

[48] Kodama, S., K. Komatsu. Y. Okumura and M. Oshimura (1992) Suppression of X-ray-induced chromosome aberrations in ataxia-telangiectasia cells by introduction of a normal human chromosome 11. Mutation Res., 293, 31-37.

[49] Zakian, V.A. (1995) ATM-related genes: What do they tell us about functions of the human gene?, Cell, 82, 685-687. 